\title{
A. D. WALLER AND THE UNIVERSITY OF LONDON PHYSIOLOGICAL LABORATORY
}

by

\section{A. H. SYKES *}

By 1900, physiology in England was a well-defined academic discipline served by independent departments with full-time professorial staff. ${ }^{1}$ Within the University of London there were twelve medical schools, each teaching physiology to its own students. These schools were, to a large extent, self-governing institutions within the federal framework of the University. As a central organization the University had been concerned only with examining and its associated administration; teaching was the responsibility of the colleges. But in 1900 the University received new statutes, which not only empowered but also encouraged it to engage in teaching activities independently of the colleges. One development under these statutes was the creation of a Physiological Laboratory for advanced teaching and research. The initiative for this extension of the University's activities was taken by A. D. Waller, largely with funds raised by him, and he directed its work for the 20 years of its existence. The history and achievements of this laboratory are described in this paper.

\section{AUGUSTUS DESIRÉ WALLER}

The concept of a university laboratory of physiology, its housing and equipping, and the direction of its work owe so much to the personal qualities of A. D. Waller that some knowledge of his life and family background is essential to an understanding of its history. There is no authoritative biography of him; the few published articles ${ }^{2}$ provide little information about his connection with the Laboratory and he left no collection of letters or other papers. He was born in Paris on 12 July 1856, the son of Augustus Volney Waller, ${ }^{3}$ FRS, who himself, although born in England, had spent much of his life in France. A. V. Waller had qualified in medicine in Paris and in London, but he gave up medicine to devote his time to physiology. He was elected FRS at the age of 34, and was twice awarded the Montyon medal of the French Academie des Sciences, one of several prestigious awards established by Baron de Montyon in the 1770 s. $^{4}$ On the second

*A. H. Sykes, MA, Ph.D., Walthwaite How, Chapel Stile, Ambleside, Cumbria LA22 9JG.

${ }^{1}$ R. D. French, 'Some problems and sources in the foundations of modern physiology in Great Britain', Hist. Sci., 1971, 10: 28-55; G. L. Geison, Michael Foster and the Cambridge School of Physiology, Princeton University Press, 1978.

${ }^{2}$ W. D. Halliburton 'A. D. Waller 1856-1922', Proc. Roy. Soc. B, 1922, 93: xxvii-xxx; Zachary Cope ‘Augustus Desiré Waller (1856-1922)', Med. Hist., 1973, 17: 380-5; E. B. Besterman and R. Creese, 'Waller-pioneer of electrocardiography', Br. Heart J., 1979, 42: 61-4; A. H. Sykes, 'A. D. Waller-a biographical note', St. Mary's Gazette, 1985, 91: 19-20.

${ }_{3}$ C. C. Gillispie (ed.), Dictionary of scientific biography, vol. 14, New York, Scribner, 1976, pp. 142-4.

${ }^{4}$ N. Egli, Der Prix Montyon de Physiologie Expérimentale im 19. Jahrhundert, Zurich, Juris, 1970. 
occasion, it was given for his work on the changes which take place when a nerve fibre is derived from its nerve cell body, known subsequently as Wallerian degeneration. He died in Geneva in 1870, and his son A. D. Waller moved to Aberdeen, where he attended school and university. Waller qualified in medicine there in 1878 and took his MD in 1881 (unfortunately his MD thesis cannot now be traced). After qualifying, he spent some months in the laboratories of Carl Ludwig ${ }^{5}$ in Leipzig and later with $\mathbf{J}$. B. A. Chauveau in Lyons. ${ }^{6}$ Waller was fluent in German and French and gave papers in both languages at International Physiological Congresses in Europe. In 1881 he joined J. S. Burdon Sanderson ${ }^{7}$ at the Department of Physiology of University College London, where he worked on the nature of fatigue in muscle and on the emerging speciality of electrophysiology then being pursued by Burdon Sanderson. During his time there he contributed to a book of exercises in practical physiology ${ }^{8}$ compiled by members of the Department to give medical students some experience of experimental methods. Hitherto, although there was a requirement for practical physiology in the medical curriculum, this had largely consisted of histology. Waller was a keen supporter of the move towards more dynamic and relevant practical classes.

In 1883 he was appointed a full time teacher of physiology at the London School of Medicine for Women (afterwards the Royal Free Hospital School of Medicine) in succession to E. A. Schaefer, ${ }^{9}$ who had given the lectures there while still attached to University College but who now wished to give them up on being appointed to succeed Burdon Sanderson in the Jodrell Chair of Physiology. Waller stayed at his new post for only a short time but long enough to meet his future wife Alice Mary Palmer, the daughter of George Palmer, founder of the biscuit manufacturing firm of Huntley and Palmer of Reading. She was a medical student at the time but did not complete the course. In 1884, on the recommendation of Michael Foster, ${ }^{10}$ Waller was appointed lecturer in charge of physiology at St Mary's Hospital Medical School. He married in 1885 and the couple moved into a large house, Weston Lodge, at 16 Grove End Road, St Johns Wood (now demolished), previously the home of the painter Philip Calderon and next door to that of Sir Lawrence Alma-Tadema (which still stands).

Waller had five children: Augustus George (1885-1967), who became a town planner; Mary Désirée (1886-1959) who became lecturer and then reader in medical physics at the Royal Free Hospital School of Medicine; William Walls (1888-1946) who qualified in medicine at Oxford and was, for a time, lecturer in physiology at Liverpool; John Claude (1891-1963) who obtained a degree in botany at Cambridge

\footnotetext{
${ }^{5}$ One of the creators of modern physiology, Ludwig's (1816-95) invention of the kymograph revolutionized graphic, quantitative recording.

${ }^{6}$ Chauveau (1827-1917) was Professor at the École Véterinaire, Lyons; he made the first measurements of cardiac pressures by intravenous catheter.

${ }^{7}$ A pioneer English physiologist, J. S. Burdon Sanderson (1828-1905) left London to become the first Waynflete Professor of Physiology at Oxford and later Regius Professor of Medicine. 1882.

8 J. Burdon Sanderson, University College course of practical exercises in physiology, London, H. K. Lewis,

${ }^{9}$ Later Sir Edward Sharpey-Schaefer (1850-1935): a leading figure in British physiology, he spent most of his career at Edinburgh.

${ }^{10}$ Zachary Cope, The history of St. Mary's Hospital Medical School, London, Heinemann, 1954 pp. 80-2; Michael Foster (1836-1907) was a founder member of the Physiological Society and first Professor of Physiology at Cambridge. For a full biography see Geison, op. cit., note 1 above.
} 


\section{A. D. Waller and the University of London Physiological Laboratory}

and was also a lecturer in physiology at Liverpool before retiring early; and Frances Alice (1894-1906) who was drowned in a shipping accident off the Channel Islands aged only 12 . The physiological world, with its lectures, laboratory work, meetings, foreign travel, and hospitality was very much part of everyday family life for the Wallers and in later years they were involved, with their father and mother, in physiological experiments at the private laboratory at home and later at the University laboratory (plate 1).

While at St Mary's Waller had an energetic and productive career. He continued to stress the importance of practical work for medical students and produced his own practical laboratory handbook. ${ }^{11} \mathrm{He}$ also joined the distinguished band of physiologists who wrote their own textbooks: his Introduction to human physiology $y^{12}$ was published in 1891 and went to three editions; it was dedicated to the achievements of his father. ${ }^{13}$ His research at St Mary's had at first been on the electrical activity of the heart and had resulted in his making the first graphic recording of the human electrocardiogram in $1887 .{ }^{14} \mathrm{He}$ then turned to a study of bioelectric potentials in nerve and other tissues and their response to anaesthetics. He was elected to the Royal Society in 1891 at the age of 35 (only a year older than his father had been upon election) and likewise he was awarded the Montyon medal in 1888 . His place in the physiological establishment was enhanced by his appointment as Treasurer of the Physiological Society, a position he held from 1896 to 1922.

Waller was appointed a Fullerian Professor at the Royal Institution in 1897, for which he was granted leave of absence from St Mary's, but he resigned the same year instead of completing the normal three-year term of office. He took the view that practical demonstrations were an essential part of advanced teaching and he found the laboratory facilities for experimental physiology, unlike those for physics, to be totally inadequate. He made the point publicly and forcibly in a letter to Nature ${ }^{15}$ and received support from C. S. Sherrington in a similar letter. ${ }^{16}$

Before taking the steps which led to the founding of the University of London Physiological Laboratory, Waller had applied for two professorial posts. In 1895 he was a candidate for the Waynflete Chair at Oxford, which had become vacant when Burdon Sanderson was translated to the Regius Professorship of Medicine. In his printed submission, ${ }^{17}$ at that time the conventional method of applying for such a post, he declared his lifelong ambition to become a professor of physiology but the post was offered to Gotch, then Sherrington's predecessor at Liverpool. In 1891 he applied for the Jodrell Chair at University College London, which had become vacant when Schaefer moved to Edinburgh. He was on the short list of candidates along with G. N.

${ }^{11}$ A. D. Waller, Excercises in practical physiology, London, Longmans, 1897.

12 Idem, An introduction to human physiology, London, Longmans, 1891.

13 The dedication reads "To the memory of my Father, Augustus Waller MD, FRS 1816-1870. Emigration of leucocytes 1846, Degeneration and Regeneration of Nerve 1850, Cilio-spinal region 1851, Vasoconstrictor aspects of sympathetic 1853".

${ }^{14}$ A. D. Waller, 'A demonstration on man of electromotive changes accompanying the heart's beat', $J$. Physiol., 1887, 8: 229-34.

${ }^{15}$ Nature, 1897, 56: 248.

16 Ibid., 1898, 57: 22-3.

${ }^{17}$ Sherrington Collection, Department of Physiology, University of Oxford. 


\section{A. H. Sykes}

Stewart, Leonard Hill, W. D. Halliburton, and E. H. Starling. From this distinguished group of candidates the electors chose Starling, who was to become perhaps the most distinguished of them all. ${ }^{18}$ Thus by 1900 , at the age of 44 , Waller had secured the headship of a department, written many research papers and a textbook, become an FRS, and was an accepted figure in English physiology. He had emulated his father in many ways but he had not yet attained his declared ambition to become a professor of physiology. This was to be achieved through the enterprise and energy which led to the foundation of the University of London Physiological Laboratory.

\section{THE FOUNDATION OF THE PHYSIOLOGICAL LABORATORY}

The University of London, since its inception as a federal university in 1836, had been subjected to continuous discussion, investigation, and legislation in attempts to define its role in teaching, examining, and administration in relation to the Colleges and other centres of higher education. ${ }^{19}$ The Gresham Report of 1894 strongly supported the concept of a single University consisting of (i) the institutions in the London area, providing full-time education to internal students, and (ii) all those institutions in the United Kingdom and British Empire which could prepare suitable students for external examination. Most importantly in the present context, the Report recommended that the University itself, independently of the constituent Colleges, should "provide lecture rooms, museums, laboratories, workshops and other facilities for the purpose both of teaching and research". The proposals were enshrined in the Statutes of 1900 which followed the University of London Act of 1898 . They were the legal basis for the foundation by the Senate of the University Physiological Laboratory. The new Statutes also provided for Boards of Studies in academic disciplines; these cut across institutional boundaries and encouraged teachers to establish common standards and generally promote the development of their subject throughout the University. One such Board was the Board of Studies in Physiology and Experimental Psychology. At its first meeting ${ }^{20}$ on 29 January 1901, attended by Waller, Sherrington, Hill, Starling, Halliburton, and Brodie, ${ }^{21}$ Waller was elected Chairman. At its fourth meeting 22 on 22 February 1901, held at Waller's house, a draft report to the Senate was considered which proposed the establishment of special university lectures in physiology to be held in a school of the University or "in a Central Institute when Central laboratories shall have been established". In June, the Board considered the concentration of studies in physiology ${ }^{23}$ and a report to the Senate was

\footnotetext{
${ }^{18}$ Special collection, University College London, Applications for Jodrell Chair in Physiology, 1899. G. N. Stewart (1860-1930) was later a Professor of Physiology in Cleveland, Ohio; Leonard Hill (1866-1952), Professor of Physiology at the London Hospital Medical School; W. D. Halliburton (1860-1931), Professor of Physiology at King's College London. E. H. Starling spent the rest of his career at University College London. He wrote an authoritative textbook and made major contributions to the concept of hormones, tissue fluid formation, and the regulation of the heart.

${ }_{19}$ N. B. Harte, The University of London 1836-1986, London, Athlone Press, 1986.

20 University of London Library, Minutes of Board of Studies for Physiology and Experimental Psychology, (henceforth cited as BS) 29 January 1901.

${ }^{21}$ T. G. Brodie (1866-1916) was lecturer in physiology at St. Thomas's Hospital, later Superintendent of the Brown Institution, and then Professor of Physiology at the University of Toronto.

22 BS, 22 February 1901.

23 BS, 13 June 1901.
} 


\section{A. D. Waller and the University of London Physiological Laboratory}

agreed, urging the University to establish an Institute of Physiology for advanced teaching and research and a series of Special University Lectures in Physiology. Matters were taken a significant stage further in November, ${ }^{24}$ when the Board requested the use of vacant rooms in the Imperial Institute at South Kensington, at that time the headquarters of the university, for delivering the lectures and for ancillary laboratory accommodation (plate 2).

The Senate ${ }^{25}$ approved the idea of special university lectures in principle and asked the Board to prepare a list of lecturers and a timetable. It was stated that "the lectures should proceed from laboratory work and be demonstrations of current research"; they were to reflect experimental not didactic teaching. It was also proposed that the laboratory space could be used for practical examinations for those taking honours physiology. The University was asked to provide basic services and furniture and to cover the maintenance costs, but the scientific equipment and technicians' wages were to be met from a grant made spcifically for this purpose by Sir Walter Palmer MP, Waller's brother-in-law and now Chairman of Huntley and Palmer of Reading. The Senate received this submission from the Board of Studies and, on 17 December 1901, an offer from Sir Walter Palmer of a grant of $£ 2000$ for equipment for some "room in the University for teaching physiology". This was accepted and a committee was established to consider the proposals in detail. ${ }^{26}$

The scheme for Special Lectures was recommended for two years in the first instance with the suggestion of a more permanent scheme within a central Institute of Physiology in the future. The Senate accepted this recommendation in January 1902 and a special resolution was moved "that the thanks of the senate be conveyed to Dr. Waller and the other gentlemen who, by generously offering their services, have enabled the University to institute lectures in advanced physiology" 27 It was subsequently reported ${ }^{28}$ to the Senate that the "laboratories have been established by the University with the object of offering facilities to workers engaged upon research for the Doctoral Thesis or for other purposes and with a view to publication of results". The Physiological Committee was reappointed ${ }^{29}$ to administer the Palmer grant, and Waller was placed in charge of the laboratory for one year. Academically, the new laboratory was in the Faculty of Science, not the Faculty of Medicine. The reason for this is not stated, but it was consistent with the organization of the Departments of Physiology at University College and King's College, which both offered the subject as part of basic science teaching for the B.Sc. degree.

Thus Waller had found academic support, financial backing, and the physical space for his new laboratory. It offered him the scope he desired as a leader of his subject "unclogged by the duties of elementary teaching" as he put it later, although at the time

\footnotetext{
${ }^{24}$ BS, 11 November 1901.

${ }^{25}$ University of London Library, Senate Minutes (henceforth SM), 589-592, 18 December 1901.

${ }^{26}$ This consisted of Sir Henry Roscoe, FRS, the Vice-Chancellor; Sir Edward Busk, the Chairman of Convocation; Sir Walter Palmer; T. L. Mears; Sir Edwin Perry, FRCP; J. R. Bradford; J. B. Farmer, FRS; W. D. Halliburton; A. D. Waller and Sir Michael Foster: all were members of Senate except Palmer and Waller, who were appointed to it later.

27 SM 1027 and 1028, 22 January 1902.

28 SM 1759, 30 April 1902.

29 SM 1459, 5 March 1902.
} 


\section{A. H. Sykes}

he was still paid as the lecturer in charge of physiology at St Mary's. In the previous year (1901) there had been a financial crisis at St Mary's ${ }^{30}$ and Waller had accepted cuts in his departmental expenditure but by now he was giving much of his time to the new University laboratory. He applied for leave of absence for this purpose in March $1902^{31}$ and again in October. ${ }^{32}$ By January 1903, Waller's continued absence from his department was causing concern and his resignation had been broached. Waller suggested a part-time arrangement since "I should feel very deeply the severing of my connection with St Mary's", 33 but he could not agree to the cut in salary which was proposed for this arrangment and his resignation was "accepted with great regret" on 18 March $1903 .{ }^{34} \mathrm{He}$ was then aged 45 and he was to spend the rest of his career, and his life, at the South Kensington laboratory.

\section{THE WORK OF THE UNIVERSITY PHYSIOLOGICAL LABORATORY}

The administration of the new Laboratory was in the hands of the Physiological Laboratory Committee appointed by the Senate and reporting annually to it. ${ }^{35}$ The Minutes of this Committee are the primary source of information about day-to-day matters. Established by a Senate Resolution of 22 January 1902, it met for the first time on 7 March. ${ }^{36}$

The accommodation in the Imperial Institute consisted of a chemical preparation room, a lecture room, a physiological preparation room, a general physiology laboratory, a store room, and an experimental psychology laboratory. The University had occupied part of the Imperial Institute since 1900, when it had moved from Burlington Gardens in order to provide more space there for the Civil Service (plate 3). The Imperial Institute was quite unsuitable for offices ${ }^{37}$ since an excessive amount of space was wasted upon wide corridors and staircases and in the considerable height of the rooms. These features were not a disadvantage for Waller's purposes, and a report in Nature $^{38}$ shows that the lecture room could seat 80 and there was laboratory space for ten workers as well as a workshop and a library. The records of the University Library Committee ${ }^{39}$ indicate that very good use was made of this collection, to which Waller contributed many of his own books.

The first series of advanced lectures was given at the Laboratory by Waller in the autumn of $1902^{40}$ and in the same year, following registration by the Home Office for experiments under the Cruelty to Animals Act of 1876, the first communication of

${ }^{30}$ Minutes of St Mary's Hospital Medical School, (henceforth MH), 19 November, 1901.

31 MH 12 March 1902.

32 MH 17 December 1902.

${ }^{33}$ MH 26 January 1903.

${ }^{34}$ MH 18 March 1903.

${ }^{35}$ This Committee was the same as the Steering Committee (see note 26, above), but without Sir Michael Foster.

${ }^{36}$ University of London Library, Minutes of the Physiological Laboratory Committee (henceforth PLC), 7 March 1902.

${ }^{37}$ Archives, Imperial College, London. D. W. Logan, Memorandum on the Section of the Imperial Institute Building Occupied by the University of London, 1956.

38 'The Physiological Laboratory of the University of London', Nature 1903, 66: 441-2; 'Some scientific centres IV', ibid., 1905, 71: 441-3.

${ }^{39}$ University of London Library, Annual Reports of Library Committee 1915-1922.

40 A. D. Waller, The signs of life, London, John Murray 1903. 


\section{A. D. Waller and the University of London Physiological Laboratory}

original research work carried out there was given to the Royal Society. ${ }^{41}$ So the Laboratory was off to a good start and it was opened officially by the Chancellor, Lord Rosebery, ${ }^{42}$ on 5 November 1902.

THE STAFF OF THE LABORATORY

A. D. Waller (1856-1922): Throughout his time at the Physiological Laboratory Waller was unpaid by the University. His income came from his wife's marriage settlement from her father and there is no record of any honorarium or expenses being paid from Laboratory funds. In February 1917 the Committee proposed ${ }^{43}$ that the Director should receive a salary but this was turned down by the Academic Council ${ }^{44}$ in May. Waller was officially designated Director after 1903, and in July 1912 he was granted the title of Professor of Physiology by the Senate ${ }^{45}$ (at the same time as W. M. Bayliss). He was then aged 56 and had finally attained his ambition.

$V$. Geets: He was the first Demonstrator in Physiology to be appointed, but he resigned on 2 December 1902 to return to his native Belgium.

N. H. Alcock (1871-1913): He succeeded Geets as Demonstrator, staying until December 1903 when he took Waller's former position as Lecturer in charge of Physiology at St Mary's. He resigned in 1911 to take the Chair of Physiology at McGill University, Montreal, where he remained until his untimely death at the age of 42 .

W. L. Symes (1868-1948): He was appointed to replace Alcock as Demonstrator and remained until the closure of the Laboratory in 1923. He was the only full-time, salaried member of staff in the history of the laboratory. He had previously been Waller's assistant lecturer at St Mary's, where he had qualified in medicine, but he resigned to join Waller again, on failing to be promoted to the Lectureship. After 1923 he taught histology for a time at St Thomas's Hospital Medical School, and later was in charge of physiology at the Royal Veterinary College.

Beatrice Edgell (1871-1948): She was appointed demonstrator in Experimental Psychology in May 1904, but she was also on the salaried staff of Bedford College and received only a small honorarium in respect of her additional post. She resigned in May 1915 to return to full-time work at her own College, where she eventually became Professor of Psychology. It was proposed that her assistant should replace her, but the appointment was never made.

J. A. Gardner ${ }^{46}$ (1867-1946): He must be looked upon as a full-time member of staff, although he was formally a lecturer, later Reader, in Physiological Chemistry at St George's Hospital Medical School. He found better facilities for his work at South Kensington and from 1905 until 1923 he was in charge of the Chemical Section of the Laboratory for which he received an honorarium. He published many papers on cholesterol metabolism during his 18-year tenure and it was during that period, in 1911, that he, along with R. H. A. Plimmer, founded the Biochemical Society.

${ }^{41}$ A. D. Waller, 'On the blaze-currents of the incubated hen's egg', Proc. Roy. Soc. B, 1902, 71: 184-93.

42 The Times, 6 November 1902.

43 PLC 14 February 1917.

44 PLC 8 May 1917.

${ }^{45}$ SM 4350, 10 July 1912.

${ }^{46}$ G. W. Ellis, 'John Addyman Gardner', Biochem. J., 1947, 41: 321-3. 


\section{A. H. Sykes}

G. A. Buckmaster (1859-1937): He was appointed Demonstrator in biochemistry, working with Gardner, but he also had a position at University College. Later he became Professor of Physiology at Bristol.

F. L. Golla (1878-1968): An honorary pharmacologist, he held appointments at St George's Hospital and the Maudsley Hospital and gave a series of Croonian Lectures (1921) while associated with the Physiological Laboratory.

The list of publications ${ }^{47}$ shows that many others, alone or in collaboration, worked at the Physiological Laboratory. Some were from other Colleges of the University and some were temporary visitors offered scientific hospitality.

\section{TEACHING ACTIVITIES}

The primary purpose of the Laboratory, as laid down by the Senate, was to provide advanced lectures in physiology for the whole of the University by lecturers drawn from the internal schools, outside organizations and the staff of the Laboratory itself. It was intended that the lectures should all be published, by John Murray, to add prestige and permanence to this new undertaking. The first course of lectures was given by Waller in the autumn of 1902 and published the following year in a volume carrying on its front cover a gilt embossed badge of the University surrounded by the words "University of London Physiological Laboratory". 48 The second series of lectures was given in 1903 by W. D. Halliburton, Professor of Physiology at Kings College. ${ }^{49}$ The following year the Board of Studies in Physiology asserted its control over the choice of subject and speakers ${ }^{50}$ and the lectures were given by Schryver ${ }^{51}$ at University College, where Schryver was on the staff, not at South Kensington: they were to be published as from "a", not "the", Physiological Laboratory of the University of London. Only seven of the lecture courses were eventually published. In addition to those already mentioned, the others ${ }^{52}$ were by G. A. Buckmaster, J. B. Leathes, Sir Lauder Brunton, and H. M. Vernon. About fifty such courses, usually of eight lectures each, were given over twenty years; Waller gave six, including one series in which he collaborated with his daughter (figure 1), and the remainder were given by physiologists of distinction including E. H. Starling, J. Barcroft, L. E. Hill, and W. B. Hardy. The Laboratory also provided a venue for scientific meetings; the Physiological Society, for example, met there on three occasions. A particularly notable meeting was that of the Chelsea

\footnotetext{
${ }^{47}$ PLC 1902-1923. The list includes the names of Sir Leonard Rogers, S. C. M. Sowton, R. H. A. Plimmer, B. J. Collingwood, P. L. Murray, M. J. Ellis, J. Seeman, G. Oliver, A. Schapiro, H. W. Bywaters, G. P. Mudge, G. D. Knox, C. B. Sanders, G. Roche Lynch, F. W. Pavy, C. Doree, H. P. Kemp, Sir Thomas Lewis, M. T. Fraser, V. H. Velley, G. W. Martyn, F. W. Hewitt, P. G. Ward, W. Godden, P. E. Lander, C. Leitham, G. de Decker, W. Burridge, F. W. Fox. Waller's wife Alice Mary, his daughter Mary, and his sons William and John contributed to the work of the Laboratory at various times.

48 Waller, op. cit., note 40 above.

49 W. D. Halliburton, Biochemistry of muscle and nerve, London, John Murray, 1904.

${ }^{50}$ BS 9 June 1904.

51 S. B. Schryver, Chemistry of the albumens, London, John Murray, 1906.

52 G. A. Buckmaster, The morphology of normal and pathological blood, London, John Murray, 1906; J. B. Leathes, Problems in animal metabolism, London, John Murray, 1906; Lauder Brunton, Lectures on the therapeutics of the circulation, London, John Murray, 1908; H. M. Vernon, Intracellular enzymes, London, John Murray, 1908.
} 


\section{A. D. Waller and the University of London Physiological Laboratory}

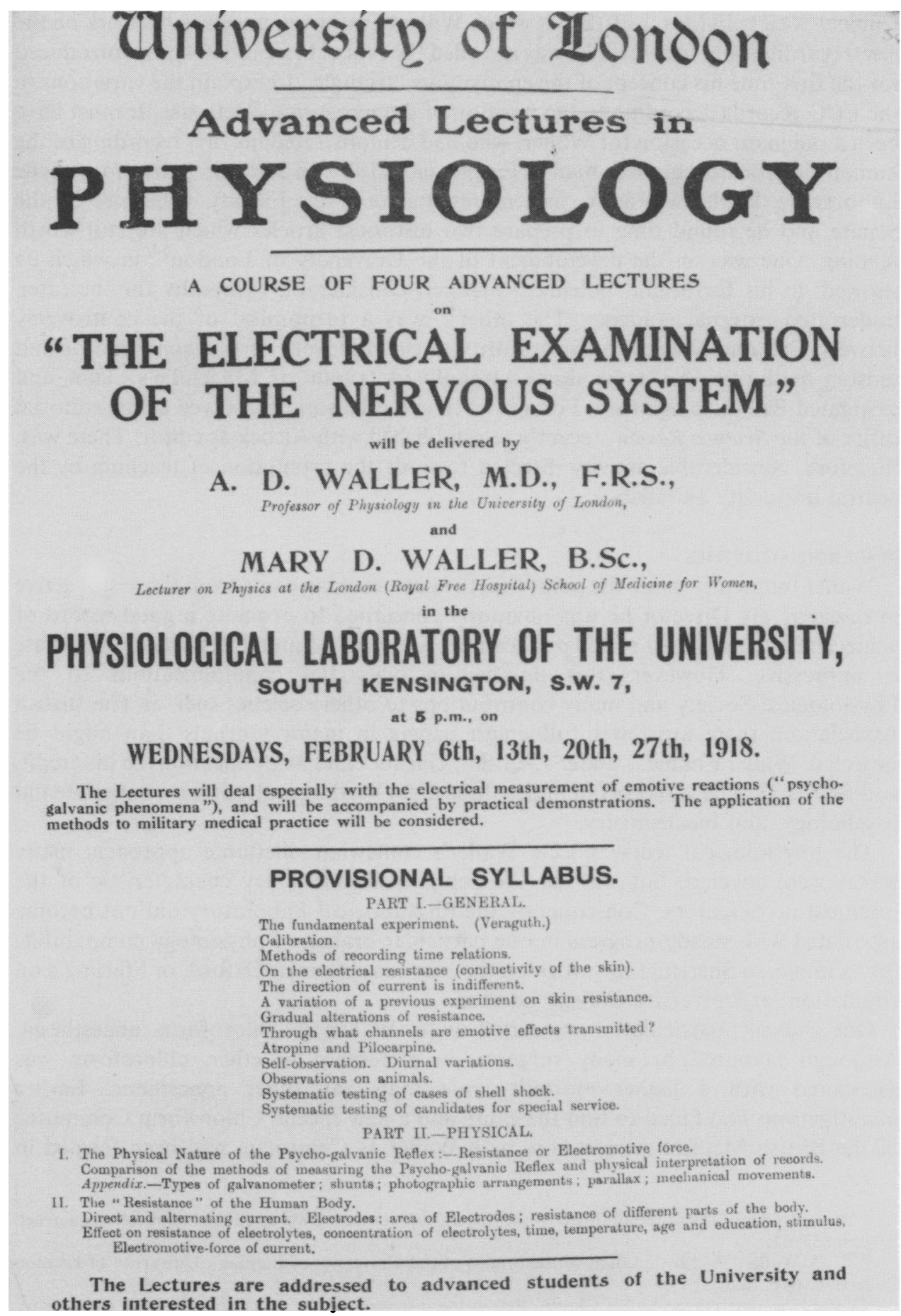

Figure 1. A poster announcing advanced lectures at the Physiological Laboratory. 
Clinical Society in March $1912^{53}$ at which Willem Einthoven reviewed his work on the electrocardiogram, for which he was awarded the Nobel Prize in 1924, and introduced for the first time his concept of the eponymous "triangle" to explain the variations in the ECG records according to the position of the measuring electrodes. It must have been a poignant occasion for Waller, who had demonstrated his first recording of the human electrocardiogram in man to Einthoven in 1887. In addition to his work at the Laboratory, Waller was active as a representative of the Faculty of Science on the Senate and he found time to prepare two historical articles which are still worth reading. One was on the development of the University of London ${ }^{54}$ in which he showed, in his forthright, polemical manner, considerable sympathy for the often underrated external students. The other ${ }^{55}$ was a reappraisal of the controversy between Bell and Magendie over priority in the discovery of the spinal motor and sensory pathways: he came down strongly in favour of Magendie's claim and castigated Bell for plagiarism. For a brief time the Laboratory served as the editorial office of the Science Review, recently re-established with Alcock as editor. There was, therefore, considerable activity directed towards the promotion of teaching by the central university authority.

\section{RESEARCH ACTIVITIES}

Waller frequently made the point that the best teaching came from those still active in research. As Director he was obviously concerned to promote a good record of achievement, and the list of 288 publications given in 21 Annual Reports to the Senate is impressive. However, this number includes 104 communications to the Physiological Society and many contributions to other societies such as The British Association; there are fewer full-length papers in major journals than might be expected. Waller's name is under 132 titles, Gardner had 44 publications to his credit, and Symes 38. The subjects fall under three main headings: physiology, experimental psychology, and biochemistry.

The physiological work reflects Waller's somewhat dilettante approach; many topics were covered, but without the depth and consistency characteristic of the foremost investigators. Consequently the Physiological Laboratory did not become associated with steady progress in one particular branch of physiology comparable, for example, to Sherrington's work on the nervous system at Oxford, or Starling's on circulation, at University College London.

One subject particularly associated with Waller is chloroform anaesthesia. Although favoured by many surgeons in preference to ether, chloroform was associated with a higher mortality rate than any other anaesthetic. Earlier investigations had failed to find the cause and a new special Chloroform Committee of the British Medical Association, with Waller as Chairman, had been formed in

\footnotetext{
${ }^{53} \mathrm{~W}$. Einthoven, 'The different forms of the human electrocardiogram and their signification', Lancet, 1912, i: 853-61.

${ }^{54}$ A. D. Waller, 'A short account of the origins of the University of London', University of London Collection, [n.p., n.d.].

${ }^{55} \mathrm{Idem}$.'The part played by Sir Charles Bell in the discovery of the functions of motor and sensory nerves (1822)', Science Progress, 1911, 21: 78-106.
} 


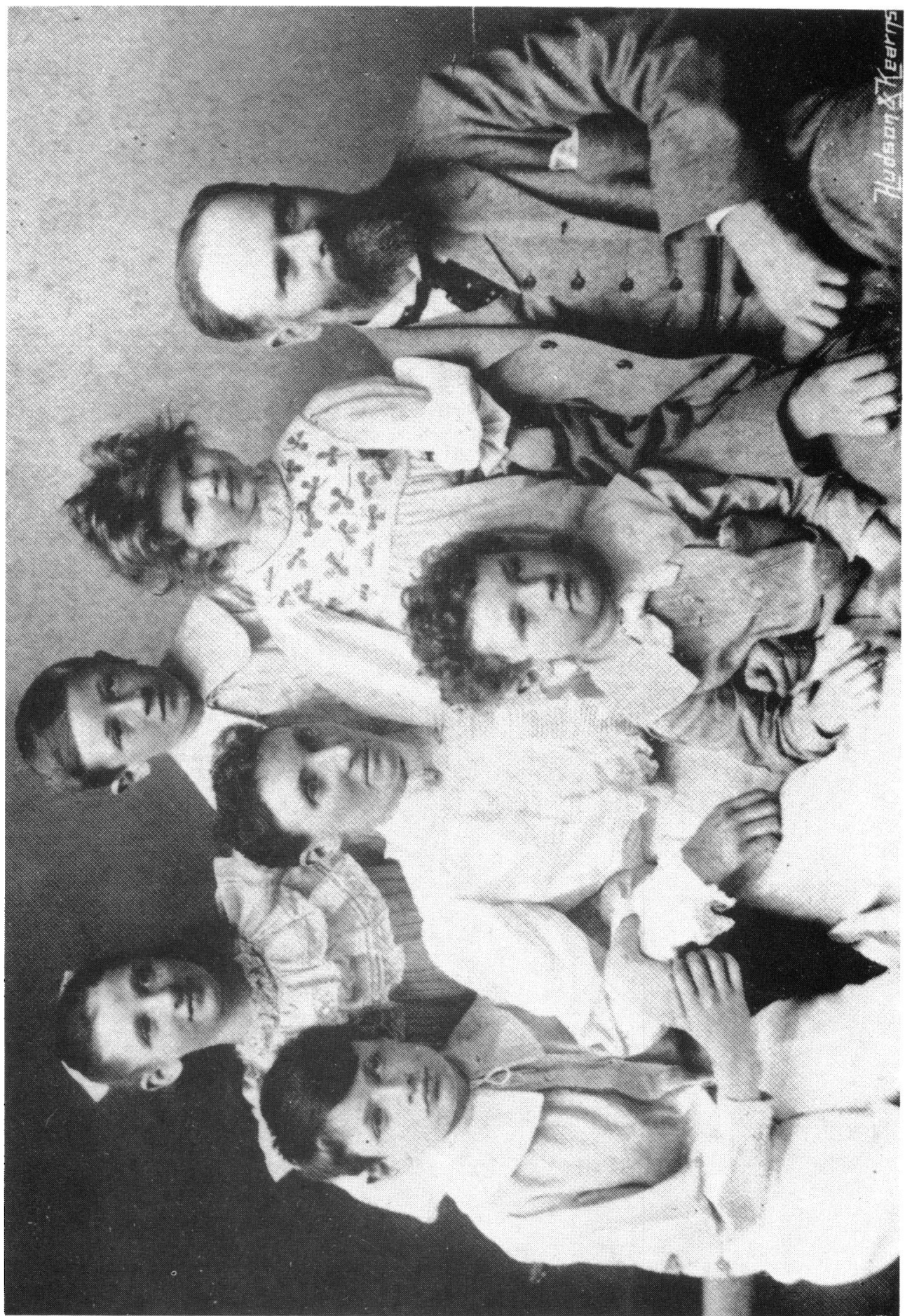

Plate 1. A. D. Waller and family, 1897. Left to right: Augustus George, Mary Désirée, Mrs A. M. Waller, William Walls, John Claude, Frances Alice, A. D. Waller. Wellcome Institute Library, London. 


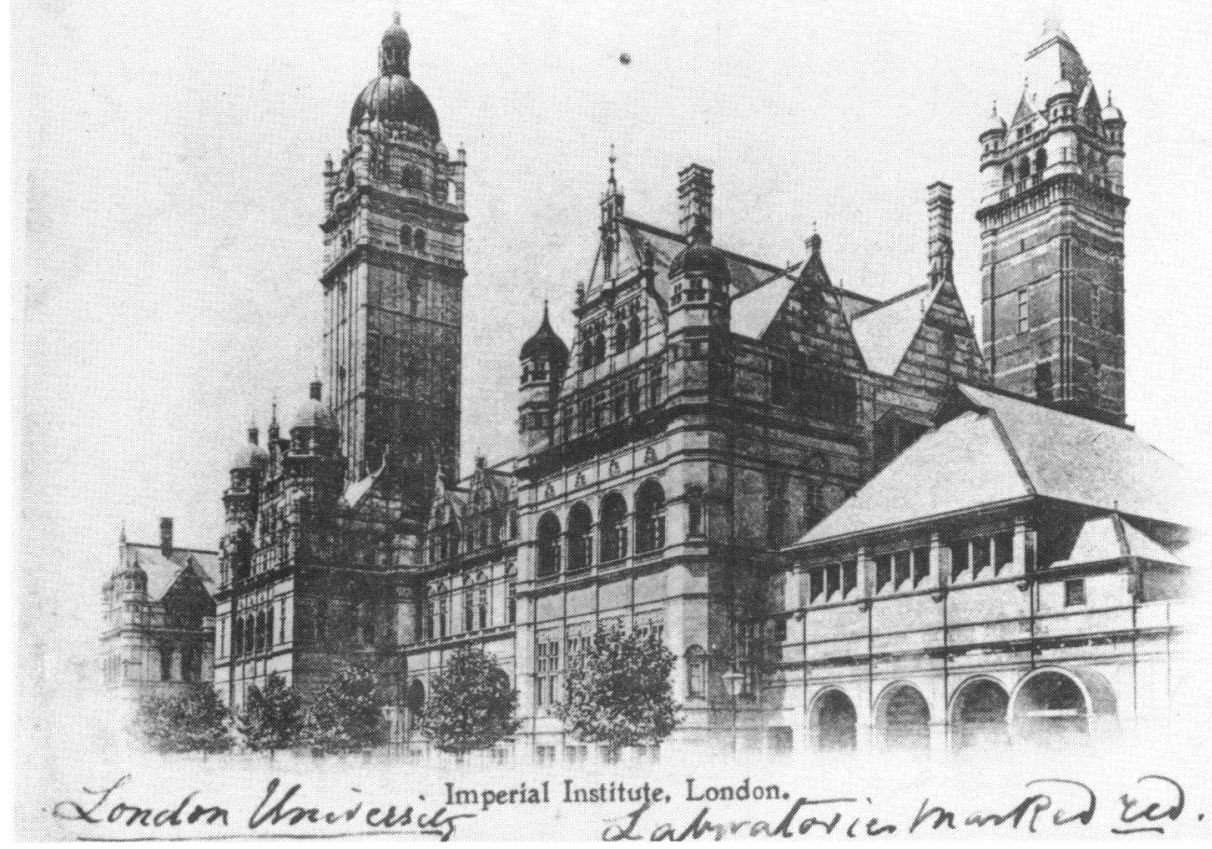

Plate 2. Imperial Institute, a postcard inscribed by Mary D. Waller, Courtesy of Carol Cheesbrough.

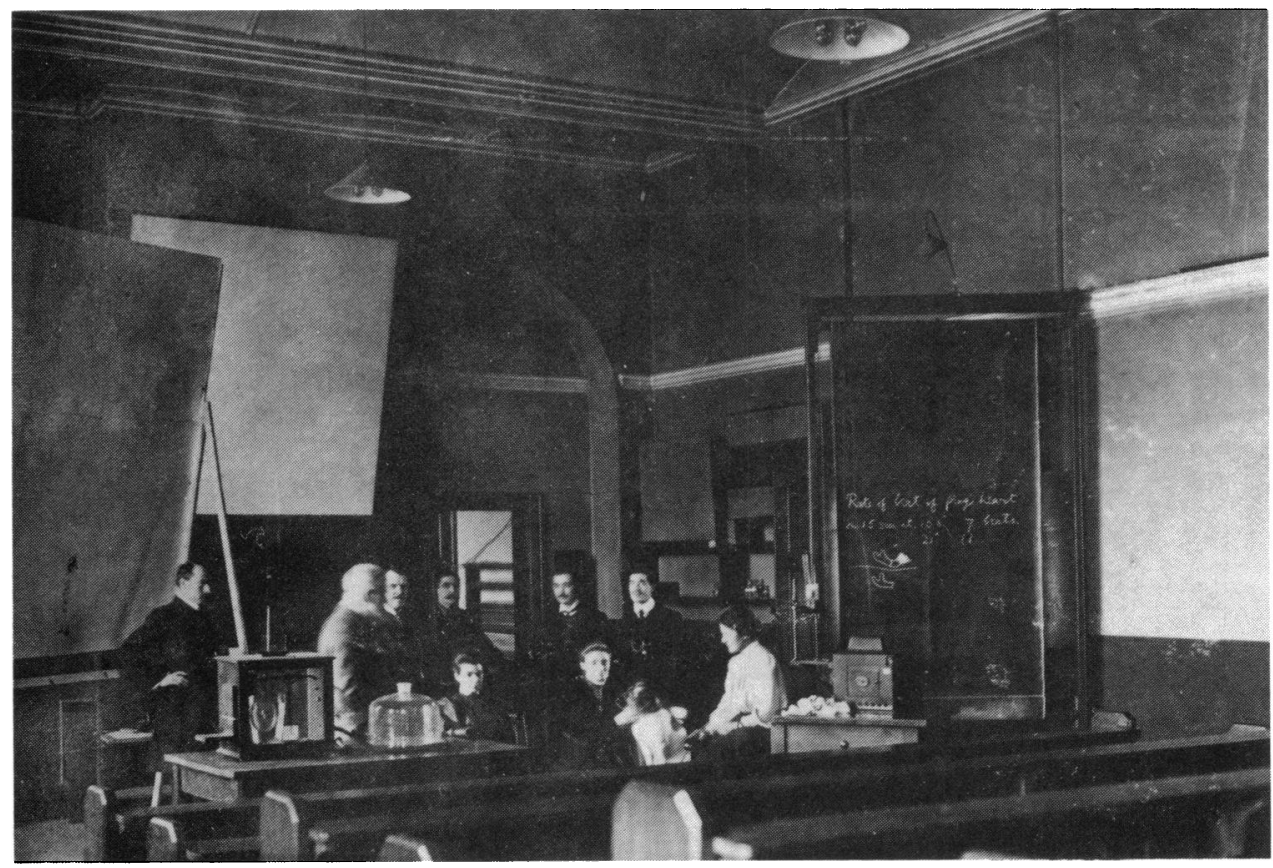

Plate 3. Inside the Physiological Laboratory, 1908. Left to right: Symes, Waller, Gardner, Sinclair, Edgell (seated), Shapiro, Mrs Waller (seated), Edwards, Kemp (seated). Mrs Waller holds Jimmie, the bulldog; a chloroform balance is on view between Symes and Waller. Courtesy of Carol Cheesbrough. 


\section{A. D. Waller and the University of London Physiological Laboratory}

1901 to reconsider the problem. The results of this inquiry and subsequent work have been described elsewhere. ${ }^{56}$ As a research interest of the Physiological Laboratory, attention was directed towards establishing quantitative methods of estimation and administration. ${ }^{57}$ Waller devised a gravimetric method for the continuous determination of chloroform in air during anaesthesia, the chloroform balance, and Buckmaster and Gardner devised a method for its estimation in blood. Alcock, although now at St Mary's, continued to work on chloroform at the Physiological Laboratory and he constructed a new type of inhaler in 1908. He, Symes, and Waller published a number of useful papers on the effects of anaesthetics on isolated muscle and nerve before the interest waned.

About 1908 Waller revived his interest in electrocardiography. At this time he was reputed to have the only string galvanometer in the country which was available for clinical work. This was the one used by Lewis at the start of his classic investigations of the heart. ${ }^{58}$ It is not clear whether it was an early Cambridge Instrument Company model or whether Waller had acquired it from a continental manufacturer. It cannot be identified from the list of early models compiled by Burnett ${ }^{59}$ or from the published history of the company. ${ }^{60}$ In 1909 he wrote an account of his visit to Einthoven in Leiden, ${ }^{61}$ and later that year he demonstrated the new string galvanometer to the Royal Society. This was the occasion when he recorded the ECG of his pet bulldog Jimmie, which led to a question in the House of Commons by a supporter of the anti-vivisection movement. Waller was completely vindicated and Jimmie acquired a measure of immortality. ${ }^{62}$ In 1911 Waller acquired another electrocardiograph jointly with the National Heart Hospital, and patients were taken to the Physiological Laboratory for examination. This arrangement lasted until 1913, when the Hospital sold its half-share in the instrument to the University and, presumably, obtained its own. Waller later published some notes on the electrical axis of the heart, but although his work helped to spread knowledge of the use of the ECG he did not directly make any major advances in cardiac electrophysiology or in its clinical application.

Another of Waller's interests was the psychogalvanic response, first observed in Zurich in 1900 . He showed that emotional factors, real or imaginery, could evoke the response. Typically, he measured his wife's reactions to an air raid on London in 1918; the sound of gunfire, approaching aeroplanes or the explosion of bombs

${ }^{56}$ K. B. Thomas, ‘Chloroform: commissions and omissions', Proc. Roy. Soc. Med., 1974, 67: 723-30.

${ }^{57}$ A. D. Waller,'The chloroform balance'. J. Physiol., 1908, 37: 6-8P; G. A. Buckmaster and J. A. Gardner, 'The estimation of chloroform in the blood of anaesthetised animals', Proc. Roy. Soc. B, 1907, 79: 309-15; N. H. Alcock, 'A new apparatus for chloroform anaesthesia', Br. Med. J., 1908, ii: 372-3.

58 T. Lewis and A.S. McNalty, "A note on the simultaneous occurrence of sinus and ventricular rhythm in man', J. Physiol., 1908, 37: 445-58. See G. E. Burch and N. P. de Pasquale, $A$ history of electrocardiography, Chicago, Year Book Publishing, 1964.

$59 \mathrm{~J}$. Burnett, 'The origins of the electrocardiograph as a clinical instrument', in W. F. Bynum, C. J. Lawrence, and V. Nutton, eds., The emergence of modern cardiology, Med. Hist. Supplement 5, London, Wellcome Institute, 1985, pp. 53-76.

${ }^{60}$ M. J. G. Cattermole and A. F. Wolfe, Horace Darwin's shop. A history of the Cambridge Scientific Instrument Company, Bristol, Adam Hilger, 1987.

${ }^{61}$ A. D. Waller, 'The electrocardiogram of man and of the dog as shown by Einthoven's string galvanometer', Lancet, 1901, i: 1448-50.

${ }^{62}$ A. H. Sykes, 'A. D. Waller and Jimmie. A centenary contribution', St. Mary's Gazette, 1987, 92: $23-6$. 


\section{A. H. Sykes}

brought about a rapid increase in her skin conductivity. ${ }^{63} \mathrm{He}$ was a gifted popularizer and one of his last public lectures was on this subject at a Friday evening discourse of the Royal Institution in 1921.64 During the war of 1914-18 the Laboratory was involved in a number of applied projects on war gases, nutrition, and the assessment of recruits. Waller determined the metabolic rate of soldiers, munition workers, dockers, and the printers of The Times, using for this purpose indirect calorimetry based upon expired carbon dioxide. His estimates were not unreasonable, but he was criticized by others in the field ${ }^{65}$ on the grounds that the calorific value of $\mathrm{CO}_{2}$ is much more variable than that of oxygen. Consequently this work never became accepted into the mainstream of human energy metabolism. Symes was involved in many collaborative papers; his own speciality was the factors which influenced the performance of the isolated frog's heart, and he devised the Symes cannula ${ }^{66}$ which was used in student practical classes for many years. The experimental psychology section did not really establish itself. There were a few communications to societies and Edgell gave one course of advanced lectures before she resigned.

The biochemistry section, essentially Gardner either alone or with collaborators, produced the greatest amount of work of lasting value from the Laboratory. After his early work on the estimation of chloroform, he commenced a study of cholesterol metabolism in man and animals. He determined the chemical nature of excretion products and how they were affected by the nature of the diet; he was one of the first to show that cholesterol could be synthesized in the animal. His examination of the factors which affect blood cholesterol levels in man was the start of an interest which has continued to the present day. The last paper in the last annual Report signed by Waller, on 15 February 1922, was by Gardner and Fox ${ }^{67}$ on cholesterol metabolism in man.

\section{THE CONCENTRATION OF MEDICAL TEACHING IN LONDON}

The existence of twelve medical schools, each offering courses in the pre-clinical subjects, had been thought to be undesirable because it made for small departments, poorly equipped and unable to provide career opportunities for able medical scientists. It was felt that some degree of amalgamation of the pre-clinical departments would be desirable on academic grounds and this was included as a future objective for the University in the Act of 1898 following the Gresham Report. ${ }^{68}$ The Senate considered the matter in $1901^{69}$ and asked for a report from the Faculty of Medicine. On 4 May of that year Waller wrote on the subject in the British Medical Journal. ${ }^{70} \mathrm{He}$ argued against a single pre-clinical centre for all the medical

${ }^{63}$ A. D. Waller, 'Galvanometric records of the emotive response to air raids', Lancet, 1918, i: 311.

${ }^{64}$ Idem, 'The electrical expression of human emotions', Proc. Roy. Inst., 1922, 23: 283-93.

${ }^{65}$ L. E. Hill and J. A. C. Campbell, 'The physiological cost of muscular work', Br. med. J., 1921, i: 733-4;

J. B. Orr and J. P. Kinloch, 'On the estimation of the physiological cost of muscular work', ibid., ii: 39-40.

${ }^{66} \mathrm{~W}$. L. Symes, 'Apparatus for perfusion of the frog's heart', J. Physiol., 1911, 43: 25P.

67 J. A. Gardner and F. W. Fox, 'Origin and destiny of cholesterol in the animal organism. On the excretion of sterols in man', Proc. Roy. Soc. B, 1921, 92: 358-67.

${ }^{68}$ Statute 80, University of London, 1900.

${ }^{69}$ SM 263, 27 February 1901.

${ }^{70}$ A. D. Waller, 'On the centralisation of medical education by the University of London', Br. med. J., 1901. i: 1066-9. 


\section{A. D. Waller and the University of London Physiological Laboratory}

schools on the grounds that this would lower the academic status of those schools, such as University College and King's College, which were developing into centres of excellence in one or more of the pre-clinical disciplines. Moreover, anatomy was already being taught successfully in the medical schools and physiology, the other main subject, could be equally well organized at the level required for routine medical students. He argued strongly instead for a central institute of advanced physiology which would set the highest standards of teaching and research for the University as a whole, that is, for an enhanced role for his own laboratory. However, the Report of the Medical Faculty, when published in December $1901^{71}$ recommended the establishment of a central institute for all pre-clinical teaching and not just for advanced research, as advocated by Waller. Not all medical opinion, however, was in favour of such a level of concentration. Leonard Hill, in a letter to the British Medical Journal $^{72}$ supported the retention by the larger medical schools of their pre-clinical departments, but he also wished to promote higher research and teaching in laboratories "such as the physiological laboratory already established in the University by the energy of Dr. Waller". However, the Senate ${ }^{73}$ backed by the Academic Council, decided to press ahead with the Faculty of Medicine's proposed scheme for a single institute and an appeal for public funds was launched in December 1903. Despite the offer of $£ 70,000$ and a free site from the Commissioners of the 1851 Exhibition, the appeal was not a success. Furthermore, the Faculty of Medicine $^{74}$ had second thoughts about the scheme and voted against it in 1905 because they feared that King's College and University College would continue with pre-clinical teaching as part of the B.Sc. degree and with a Central Institute in addition the remaining hospital medical schools would no longer be viable. The Senate was forced to abandon the scheme and refund the donations that had been made. ${ }^{75}$ Subsequently in 1908 two medical schools, The Westminster and St George's, gave up pre-clinical teaching, but in other schools the pre-clinical departments became more firmly established. The University Physiological Laboratory was apparently unaffected by this controversy but, as will be seen, the failure to initiate some scheme of centralization ultimately worked against its long-term interests since the other college Departments of Physiology, now no longer threatened, expanded their own teaching and research activities.

\section{THE CLOSURE OF THE PHYSIOLOGICAL LABORATORY}

The immediate causes of the closure were the withdrawal of the London County Council (LCC) Grant and the demand for further space by the University administration. The LCC first made a specific grant of $£ 500$ in support of the Laboratory in 1911 , which supplemented a University grant of $£ 800 .^{76}$ In 1914 , at the request of the University, all LCC grants to the University were consolidated, and in

\footnotetext{
${ }^{71}$ University of London Library, Report of the Medical Faculty to Senate, 13 December 1901.

$72 \mathrm{Br}$. med. J., 1905, i: 510-11.

73 SM 433, 18 November 1903.

74 University of London Library, Report of the Medical Faculty to Senate, 20 February 1905.

${ }^{75}$ SM 1130, 20 February 1905.

76 PLC 4 July 1912.
} 


\section{A. H. Sykes}

the same year the Laboratory Committee was asked by the Senate to refund all unused money in order to meet increasing University costs. ${ }^{77}$ In 1917 the LCC questioned the need for any grant-in-aid for the Laboratory on the grounds that there already existed adequate facilities for physiological teaching and research in the Schools of the University without the need for an additional Senate institute. ${ }^{78}$ Later that year the Academic Registrar ${ }^{79}$ asked for more office space, and some of the rooms, including the large lecture room, were surrendered. The Committee members were aware of the increasingly uncertain future of the Laboratory, and in $1919^{80}$ they put forward a request to the Senate for a considerable increase in the University grant so as to provide for a fully salaried staff, including the Director, and to cover increased maintenance costs. Meanwhile the pressure for space continued and in October 1919 the Academic Council suggested ${ }^{81}$ that the Laboratory should be moved from the Imperial Institute to the Brown Animal Sanatory Institution ${ }^{82}$ in Wandsworth. Waller and his Committee visited the Brown Institution in November, but they did not find the conditions there were suitable for them. The little space available was dilapidated, and the whole site was considered to be too remote. Buchanan, Chairman of the Brown Committee, suggested that both the Brown and the Physiological Laboratory should together move to another site. ${ }^{83} \mathrm{Had}$ this proved possible then, the continued existence of both institutions might have been assured, whereas, in the event, both were closed.

In 1920 the $\mathrm{LCC}^{84}$ once again questioned the continuation of support for the Physiological Laboratory and on 15 December the Senate passed the following Resolutions. "That failing the assurance of adequate support from the London County Council or other sources before the end of March 1921, arrangements be made to close the Physiological Laboratory not later than the end of July 1921 "85 and "That should adequate support for the transference and maintenance of the Physiological Laboratory be forthcoming the Laboratory be continued during the pleasure of the Senate elsewhere than its present headquarters which shall be vacated not later than the end of July 1921". ${ }^{86}$ The Board of Studies ${ }^{87}$ expressed its total support for the Laboratory, and asked the Senate to reconsider its decision. The Standing Committee of Convocation did likewise. ${ }^{88}$ The Physiological Society, in a resolution ${ }^{89}$ transmitted to the Senate, the $\mathrm{LCC}$, and The Times, stated that "the closure of the Physiological Laboratory of the University would be a gross injury to

${ }^{77}$ PLC 10 November 1914.

${ }^{78}$ PLC 2 May 1917.

${ }^{79}$ PLC 5 December 1917.

${ }^{80}$ PLC 7 May 1919.

81 PLC 17 October 1919.

82 G. S. Wilson, 'The Brown animal sanatory institution', J. Hyg. (Camb.), 1979, 82: 155-76, 337-52, 501-21; 1979, 83: 171-97.

${ }_{83}^{82}$ PLC 18 November 1919.

${ }^{84}$ PLC 13 October 1920.

${ }^{85}$ SM 1317, 15 December 1920.

${ }^{86}$ SM 1318, 15 December 1920.

${ }^{87}$ BS 20 January 1921.

${ }^{88}$ University of London Library, Proceedings of Convocation, pp. 168-9, 3 May 1921.

${ }^{89}$ Archives Centre, Churchill College, Cambridge, Physiological Society, Minutes of Scientific Meetings, 22 January 1921. 


\section{A. D. Waller and the University of London Physiological Laboratory}

the advancement of science and knowledge and teaching of physiology in London. Such a closure would be contrary to the public interest". Schaefer (by then Sharpey-Schaefer) also wrote to The Times, ${ }^{90}$ strongly opposing the Senate decision: under the heading 'Physiology in London: a unique laboratory', he asserted that "closure would be little short of disastrous for the progress of physiological research in London"; its strength is that it has no elementary teaching . . . [and is] able to devote all its energies to research"; "the brilliant results of A. D. Waller especially in the difficult field of electrophysiology are well known" and finally "the LCC will contract $£ 3$ million to a Bloomsbury site which is not even planned. It is a pity to allow an active laboratory to be abolished in order to save $£ 500$ a year towards the cost of problematical buildings". Sharpey-Schaefer had the respect and friendship of Waller over many years. They were at University College together and he effectively gave Waller his first lectureship at the Royal Free Hospital School of Medicine. They exchanged letters on many professional matters and Waller was an enthusiastic supporter of the new Quarterly Journal of Experimental Physiology, founded by Sharpey-Schaefer in 1908.

The Senate obviously took note of these views since on 16 March $1921^{91}$ it not only suspended the closure notice but also increased its grant to $£ 1000$ to cover in part the deficit caused by the LCC, which still (7 February 1921) declined to renew its grant. The LCC ${ }^{92}$ reminded the Senate that "the Physiological Laboratory grant had been absorbed into the general fund during the war and the central organisation had a surplus of $£ 30,000$, enough to support the Laboratory in the present triennium". The Senate ${ }^{93}$ still insisted upon possession of the space at South Kensington but it extended the notice to the end of 1923. By then a new site would have to be found, but the Laboratory itself would continue to exist. Waller was delighted; he wrote to Sharpey-Schaefer ${ }^{94}$ (17 March 1921) "we've won the first round". He went on to add, characteristically, "P.S. I got a capital photograph of my own emotive state during the two hours of palaver downstairs". But he was aware that the fight for survival would continue. He wrote again to Sharpey-Schaefer, ${ }^{94}$ "Thanks to you and others I have two years to live in this laboratory and the two considerations clearly before me are: 1 . to leave the laboratory as a going concern for other people; 2 . to work in it myself in reasonable comfort during the said two years (or more?). Meanwhile the conditions are so unfavourable through the fixed and undisguised ill-will of the London University authorities that I have no reasonable expectation of fulfilling either of these desiderata". He went on to say that he was looking into the possibility of working at the Marey Institute near Paris, and sought the approval of English physiologists since he did not wish such a move to appear to be an act of pique. One of his last attempts to influence the course of events was the publication of a letter in the

${ }^{90}$ E. A. Sharpey-Schaefer, Letter, The Times, 13 January 1921.

91 SM 2884, 16 March 1921.

92 Archives Centre, Churchill College, Cambridge. Physiological Society minutes of Scientific Meetings, 22 January 1921. London County Council letter, reference H4, 7 February 1921.

93 SM 2890, 16 March 1921.

94 Contemporary Medical Archives Centre, Wellcome Institute, London: A. D. Waller, letters to E. A. Sharpey-Schaefer 17 March 1921 and 29 May 1921. 


\section{A. H. Sykes}

Lance ${ }^{95}$ in which he compared the research output of several organizations as shown by their number of publications in the Proceedings of the Royal Society $(B)$ over the period 1905 to 1920. As might be expected, this showed the small Physiological Laboratory in a very favourable light with 40 publications compared with Imperial College's 52, University College London's 46, and King's College's 25. It was a fair point to make in the circumstances but it was almost certainly too late to carry much influence.

Despite the Senate's new attitude, Waller was still having problems with the accommodation at South Kensington, and his appeal for the return of the lecture room was turned down by the vice-chancellor ${ }^{96} \mathrm{He}$ had to give his lectures at St Mary's and the Royal Free Hospital where he had commenced his career in the 1880s. At this critical time for the Physiological Laboratory Waller died on 11 March 1922, aged 65. He had earlier survived a mild stroke, but he succumbed to a more severe one and was buried in Finchley Cemetery. His death was noted by the Senate with regret and his services to the University duly acknowledged, but at its meeting on 22 March, 11 days after Waller's death, the Senate ${ }^{97}$ voted to adopt its former resolution of December 1920 "in so far as it relates to the vacation by the Physiological Laboratory of its present quarters takes effect at the end of the session 1922/23". An attempt to refer the matter back to the Academic Council was defeated. The Board of Studies was asked to consider the future of the Laboratory and in January 1923 a proposal to locate it in two huts in the grounds of the Brown Institution was considered by the Senate. ${ }^{98}$ Despite the suggestion to call it the "Wallerian Laboratory of Comparative Physiology", the senate did not like the idea of ex-army huts constituting a university department, and the Finance Committee did not approve of the additional expenditure. It pressed for closure of the laboratory, a view which was supported by Professor J. Rose Bradford, a member of the originating committee in 1902, who now considered that there was no need for more physiological laboratories in the University and that the Brown should confine its activities to experimental pathology. There was no last-minute reprieve this time and the remaining rooms in the Imperial Institute were given up. The equipment was dispersed within the University and on 24 October it was reported to Senate ${ }^{99}$ that a balance of $£ 120.1 \mathrm{~s} .0 \mathrm{~d}$. had been transferred to General Funds and that the conversion to office accommodation was proceeding. The library, including Waller's own books, was intended to be kept intact as a section of the University library "and be developed in connection therewith as a memorial to the late A. D. Waller". ${ }^{100}$ In the event the books were dispersed among the general collection, but they may still be recognized by a special commemorative bookplate.

\section{THE BACKGROUND TO THE CLOSURE OF THE PHYSIOLOGICAL LABORATORY}

The University had accepted that the Imperial Institute was not suitable as a permanent headquarters, and the possibility of moving to a new site in Bloomsbury was being discussed before 1914. But the day-to-day problems of providing space had to

\footnotetext{
95 A. D. Waller, 'The output of research places in the United Kingdom', Lancet, 1921, ii: 977.

96 PLC 9 March 1921.

97 SM 2492, 22 March 1922.

98 SM 1292-1297, 24 January 1923.

99 SM 95, 24th October 1923.

100 SM 938, 21 November 1923.
} 


\section{A. D. Waller and the University of London Physiological Laboratory}

be solved, and the exigencies of the war had already forced Waller to give up some accommodation. The pressure for more space continued, and it was clear to Waller that he now lived in a hostile environment and it was inevitable that the Laboratory would eventually have to move. The financial situation was precarious, and not made any easier by Waller's honorary status since he was over 60 at the end of the war and a successor would certainly have to be paid a normal salary. The Committee's more realistic proposals about running costs amounted to $£ 7000$ per annum, which did not compare favourably with the costs of other Departments of Physiology (University College $£ 6500$, King's College $£ 3000$, The London Hospital $£ 2400$, and even lower costs elsewhere). Moreover, many of these Departments not only carried out research and advanced teaching but did so while undertaking the routine teaching of large numbers of medical students. In the short term, the additional sum needed to make good the deficit brought about by the refusal of the LCC to continue its support was relatively small, and had there been strong academic grounds for the continued existence of the Laboratory then, no doubt, the funds would have been made available on a basis more permanent than "during the pleasure of the Senate".

However, the academic foundation of the Laboratory was unsound and in some respects had been so from the beginning. It was established primarily for teaching purposes; it was intended to fill the need for specialized lectures available to all the science departments of the University, and to allow the Senate to become directly involved in teaching as recommended in the Gresham Report. But it was not long before such special lectures were being arranged, with the approval of the Senate, by several of the Schools themselves; for example, Pavy gave a course of advanced lectures in 1905 which were subsequently published, but not by Murray and without Waller's involvement. ${ }^{101}$ It is pleasing to note that during the session in which he gave these lectures, Pavy made a donation of $£ 100$ to the funds of the Physiological Laboratory; ${ }^{102}$ a nicely-timed gesture of support for the originator of such lectures. In 1912 an inter-collegiate B.Sc. degree in physiology was instituted which, with its lectures and practical classes provided by several existing Departments, further eroded the hitherto unique position of the Physiological Laboratory. Physiology was an expanding subject and did not require the support of the Senate which might have been necessary for such minority subjects as the history of art in order to be viable. Neither was Waller's Laboratory a centre of specialization in one particular new and important aspect of physiology comparable with such medical specialities as orthopaedics or urology, which later formed the basis of postgraduate institutes. The Laboratory was isolated, in the sense that it did not have a strong administrative parent body such as that provided by a college organization, and its lack of involvement with routine undergraduate teaching removed another justification for its continued existence. By contrast, Starling, at University College, not only coped with medical and science students but produced research work of distinction and attracted outside funds for new laboratories which, when opened in 1909, were boldly named on an iron plaque (still to be seen), the "Institute of Physiology". ${ }^{103}$ (There had

${ }^{101}$ F. W. Pavy, Carbohydrate metabolism, London, J. \& G. Churchill, 1906.

102 SM 1270, 29 March 1905.

${ }^{103}$ Editorial, 'A New Institute of Physiology in London', Br. med. J., 1909, i: 1436-44. 


\section{A. H. Sykes}

been plans for a more ambitious Institute of Medical Sciences as part of a scheme for the concentration of medical teaching.) Waller showed no such enterprise and there is no evidence that he ever sought outside grants or attempted to increase the numbers of his established staff.

The Gresham Report, and the subsequent legislation, did not resolve all the constitutional problems of the University and in 1909 a new Royal Commission was appointed under the chairmanship of R. B. Haldane. Submissions were accepted from all sections of the University, including one from the Physiological Laboratory Committee. Published in 1913, the Haldane Report ${ }^{104}$ expressed the view that specialist research institutions should not have an independent existence within the University and that all academic staff should have college appointments and thus be able to influence teaching at all levels. This view was diametrically opposed to that of Waller, who wished for an institute which would be "unclogged by the duties of elementary teaching". ${ }^{105}$ The Haldane Commission specifically recommended that the Laboratory should no longer exist independently but should be transferred to one of the other Schools: University College was mentioned as a possibility, but since the department there already had two professor (Starling and Bayliss), it was thought that King's College, with only one professor (Halliburton), might be more suitable. The Report also took the view that there was no urgency to provide central laboratories in University buildings. It considered the position of the Brown Institution, also an independent laboratory, and recommended that it too should be relocated, possibly in close connection with the Royal Veterinary College, where it might become more involved in the routine work of University teaching. There were, however, complicated legal reasons why this recommendation could not be acted upon. ${ }^{106}$ The Physiological Laboratory Committee ${ }^{107}$ and the Faculty of Science ${ }^{108}$ emphatically disagreed with the academic principle expressed by the Haldane Commissioners. However, the latter's view prevailed and when the Senate next promoted an organization for advanced teaching and research, the Institute of Historical Research in 1921, it laid down that the staff remained members of one of the Schools, and that the organization provided, under a Director, only a specialist library and a framework for its inter-collegiate activities. This has remained the pattern for many subsequent Senate institutes and central laboratories have remained a long-forgotten aim of the Gresham Commissioners. Although the Physiological Laboratory eventually closed, its inception marked the start of a number of academic developments in the University such as inter-collegiate co-operation, special University lectures, and Senate Institutes, which can be traced back to Waller's initiative.

\section{ACKNOWLEDGEMENTS}

I wish to thank especially Miss Helen Young of the Senate House Library, University of London, for her ever-patient help in providing material for this article. My thanks are also due to all the many archivists and librarians, too numerous to list, who dealt so efficiently with my enquiries.

\footnotetext{
104 Royal Commission on University Education in London, Final Report, 1913.

105 Waller, op. cit., note 70 above.

106 Wilson, op. cit., note 82 above.

107 PLC Annual Report to Senate 12 February 1914.

108 University of London Library, Faculty of Science, Report on the Royal Commission, 26 May 1914; Faculty of Science Minutes, 28 May 1920.
} 